\title{
Histopathological alterations observed in the liver of Poecilia vivipara (Cyprinodontiformes: Poeciliidae) as a tool for the environmental quality assessment of the Cachoeira River, BA
}

\author{
Paulo, DV. ${ }^{a, b *}$, Fontes, FM. ${ }^{a}$ and Flores-Lopes, $F^{b *}$. \\ aPrograma de Pós-Graduação em Sistemas Aquáticos Tropicais, \\ Universidade Estadual de Santa Cruz - UESC, Rod. Ilhéus-Itabuna, Km 16, Ilhéus, BA, Brazil

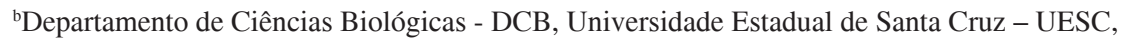 \\ Rod. Ilhéus-Itabuna, Km 16, Ilhéus, BA, Brazil \\ *e-mail: drielevp@hotmail.com; fabiologo5@hotmail.com
}

Received September 20, 2010 - Accepted June 16, 2011 - Distributed February 29, 2012

(With 5 figures)

\begin{abstract}
Histopathological alterations in liver have been widely used as a tool in studies for monitoring environmental quality. To evaluate the environmental quality in the Cachoeira river, five spots were monitored between the municipal districts of Itapé and Ilhéus, using liver histological analysis. The species chosen for analysis was Poecilia vivipara due to the fact that it is one of the most abundant in the sampling. The routine technique of inclusion and impregnation in paraffin was used, and the cuts were stained with Hematoxylin and Eosin ( $\mathrm{H} \& \mathrm{E})$. Histopathological alterations in the liver were evaluated semi-quantitatively and based on the severity of the lesions. The results of the histopathological alteration frequency together with the average taken from the Histopathological Alteration Index from points 1 (Vila de Itapé) and 2 (Fazenda Santa Amélia) showed that in this area the environment is more threatened because of some stressor agent, possibly contaminants that seem to be acting in the environment and endangering the health of fish. The statistic results demonstrated that there were no significant differences among points 1,2 and 4, which means they are very similar to one another, and are ecologically endangered.
\end{abstract}

Keywork: Poecilia vivipara, toxicology, histopathologic alterations.

\author{
Alterações histopatológicas observadas no fígado de Poecilia vivipara \\ (Cyprinodontiformes: Poeciliidae) como ferramenta de avaliação \\ da qualidade ambiental do rio Cachoeira, BA
}

\begin{abstract}
Resumo
Alteraç̃es histopatológicas em fígado têm sido amplamente utilizadas como ferramenta no estudo de monitoramento da qualidade ambiental. A fim de avaliar a qualidade ambiental do Rio Cachoeira, foi realizado um monitoramento em cinco pontos do rio, entre Itapé e Ilhéus, utilizando-se análise histopatológica do fígado. A espécie Poecilia vivipara foi escolhida para análise por ser uma das mais abundantes nas amostragens. Foi utilizada a técnica histológica de rotina de inclusão e impregnação em parafina, sendo os cortes corados com hematoxilina e eosina (H\&E). As alterações histopatológicas no fígado foram avaliadas semiquantitativamente e baseadas na severidade das lesões. Os resultados das frequências de alterações histopatológicas juntamente com as médias de IAH dos pontos 1 (Vila de Itapé) e 2 (Fazenda Santa Amélia) demonstraram que nestas áreas os ambientes encontram-se mais comprometidos por causa da atuação de algum agentes estressores, que possivelmente, seja contaminante que deve estar atuando sobre o ambiente e comprometendo a saúde dos peixes. Os resultados dos testes estatísticos demonstraram que não houve diferença estatisticamente significativa entre os pontos Vila de Itapé, Fazenda Santa Amélia e Ponto do Pitu, e que ambos - pontos Vila de Itapé, Fazenda Santa Amélia - estão comprometidos ecologicamente, apesar de o ponto Fazenda Santa Amélia ser considerado o mais degradado de acordo com as frequências de alterações e o IAH.
\end{abstract}

Palavras-chave: Poecilia vivipara, toxicologia, alterações histopatológicas. 


\section{Introduction}

Pollution on freshwater surfaces is a major environmental problem worldwide (Lobo et al., 2002). Deterioration in these environments due to human activities has created a need for developing and adjusting methods for environmental quality (Bruschi Junior et al., 2000).

Different methods have been used in studies relating to human impact on aquatic organisms. The methods are used for the purpose of detecting and measuring the intensity of the impact caused by the presence of contaminants on the aquatic ecosystem and the potential toxic effects of chemicals in these organisms (Martinez et al., 2004). Currently, bioindicators and biomarkers have been used in assessing the toxicity of chemical compounds of anthropogenic origin in impacted areas (Oliveira-Ribeiro et al., 2005). Moreover, histopathological biomarkers have shown to be excellent tools for monitoring the balance of the aquatic ecosystem (Winkaler et al., 2001) and for elucidating mechanisms of action of various types of stress agents and on the physiological conditions of organisms (Zagatto, 2006). Taking this into account, pathological examinations have been recognized as useful tools for assessing the effects of pollutants in fish by examining them for morphological alterations in their bodies (Poleksic and Mitrovic-Tutundzic, 1994), whereas the contamination increase in these ecosystems has promoted severe morphological and physiological alterations in aquatic organisms (Mazon et al., 1999).

Histological analysis provides a fast and efficient process to express the health of organisms exposed to a contaminated environment. When coupled with other tools such as physical-chemical and toxicological properties of water it is possible to infer a more precise diagnosis of the environment under study and the possible reasons for the conditions observed, since the alterations in specific target organs may also express time of exposure to a specific stressor (Schmalz et al., 2002). Histopathological alterations of specific organs express the conditions and represent endogenous and exogenous impacts on organisms that originate from alterations in lower levels of biological organization (Stebbing, 1985). Currently, physiological and histopathological biomarkers are used extensively for documenting and quantifying exposure, as well as the effects of environmental pollutants. As monitors of exposure, these biomarkers have the advantage of quantifying only pollutants that are biologically available. As monitors of effects, biomarkers can integrate the effects of multiple stressors and help in the elucidation of mechanisms of action (Adams et al., 1990).

The liver, as the largest organ of metabolism and for having potential for biotransformation and excretion of xenobiotics bioactivation, comes into direct contact with pollutants absorbed from the environment (Gonzalez et al., 1993; Bernet et al., 1999), therefore lesions in these organs are often associated with pollution of the aquatic environment.

The Cachoeira River Basin covers one of the major socioeconomic regions of Bahia (Nacif, 2000). It has undergone an intense process of degradation, mainly caused by the discharge of untreated municipal sewage into its waters, the use of fertilizers and pesticides on cocoa plantations and the illegal presence of tanneries in the bank (Souza et al., 2009). Poecilia vivipara (Bloch and Schineider, 1801) is a Cyprinodontiformes original species of northern South America between Venezuela and the Brazilian state of Amapá (Lucinda and Costa, 2007) and its vast distribution throughout South America has been widely used as a bioindicator in programs for monitoring the aquatic environment due to its sensitivity to contaminants and tough response (development of disease and histopathological alterations) and because it is abundant at polluted sites with low dissolved oxygen (Breseghelo et al., 2004).

This work aimed to monitor the environmental quality of the Cachoeira river in order to compare the environmental quality of the sampled spots by using histopathological analysis in the liver of Poecilia vivipara.

\section{Material and Methods}

The Cachoeira river basin is located in southern Bahia, Brazil between coordinates $14^{\circ} 42^{\prime}-15^{\circ} 20^{\prime} \mathrm{S}$ and $39^{\circ} 01^{\prime}-40^{\circ} 09^{\prime} \mathrm{W}$ and drains an area of approximately $4830 \mathrm{~km}^{2}$ and to the east by the Atlantic Ocean (Oliveira, 1997 apud Schiavetti et al., 2002). Four quarterly samplings were performed for one year, from June, 2007 to June, 2008. Collecting was done using a seine net $(5.5 \mathrm{~m} \times 1.5 \mathrm{~m} \times 0.5 \mathrm{~cm})$ and puçá types (Malabarba and Reis, 1987), at five spots along the Cachoeira river, between the cities of Itapé and Ilhéus (point 1 - Vila de Itapé (14 $53^{\circ}$ ' 934' S and 39 $25^{\circ}$ '781' W); point 2 - Fazenda Sta. Amélia - Itapé (14 52' 719” S and $39^{\circ} 24^{\prime} 772^{\prime}$ 'W); point 3 - in front of Jardim das Acácias - Itabuna $\left(14^{\circ} 47^{\prime} 20^{\prime \prime} \mathrm{S}\right.$ and $\left.39^{\circ} 15^{\prime} 41^{\prime \prime} \mathrm{W}\right)$; point 4 near Ponto do Pitú (14 $47^{\prime} 788^{\prime}$ ' S and $39^{\circ} 12^{\prime} 107^{\prime}$ 'W) and point 5 - Caminho das Sesmarias (14 47'072" S and $39^{\circ} 06^{\prime} 273$ ” W) (Figure 1)

The sampling spots were defined by using a pilot sampling and according to conditions for access to the river. Point Itapé was chosen as a comparative point because of its location upstream from Itabuna at a distance of $32 \mathrm{~km}$ from that municipality due to its proximity to the confluence with the Salgado river and because it was considered to have the best environmental quality for the presence of metals according to studies by Klumpp et al. (2002).

The specimens were fixed in the field in $10 \%$ formaldehyde. In the laboratory, the material was screened, identified for the species level and preserved in 70\% alcohol, then it was deposited in the Ichthyology collection at the Universidade Estadual de Santa Cruz - UESC.

When possible, ten specimens of Poecilia vivipara from each sampling spot were used for analysis. Measurements were made for the standard length (SL) and total weight (TW). The liver was then removed and placed in $70 \%$ alcohol. The liver was prepared for histological analysis by a routine technique of dehydration in ethanol and then 




Figure 1. Map of Bahia State and, in detail, the basin of the Cachoeira River showing the sampling points. 1) Itapé; 2) Fazenda Sta. Amélia; 3) Jardim das Acácias; 4) Ponto do Pitú; 5) Caminho das Sesmarias.

impregnation and embedding in parrafin. Sections of 5-7 $\mu \mathrm{m}$ were made with microtome. The sections were stained with hematoxylin and eosin (H\&E) for general visualization of the affected tissues and organs.

Histopathological alterations were classified using scores of from 0 to 3 , where $0=$ no alteration, $1=$ slight alteration, 2 = moderate and $3=$ severe alteration according to Hose et al. (1996). Definitions for slight, moderate and severe alteration were modified from Poleksic and MitrovicTutundzic (1994), and characterized as follows: 1) slight alteration - alterations that do not damage organ tissues in such a way as to impede restructuring and returning of normal liver functions should environmental conditions improve. They are restricted to small parts of the organ. Example: hepatocyte vacuolation. 2) Moderate alterationalterations that are more severe and that lead to effects on tissues associated with organ function; theses are reparable lesions, but if large areas of the organ are affected or maintained under chronic pollution conditions, they may direct towards severe alterations. They occur in practically the entire organ. Example: degeneration of cytoplasm and nucleus. 3) Severe alteration - recovery of organ structure is not possible, even with an improvement in the quality of water or end of exposure to a toxic stimulus. Example: tumor formation and alteration in the exocrine pancreas. Based upon this scale, average values were calculated so as to evaluate anomaly intensities for each sampling spot (Table 1).

The presence of histopathological alterations in the liver was assessed semi-quantitatively using the degree of tissue alternation (Histopathological Alterations Index - HAI) based on the severity of lesions. To calculate the HAI (modified from Poleksic and Mitrovic-Tutundzic,
1994), the alterations in each organ were classified in progressive tissue damage stages (Table 1). An HAI value was calculated for each animal using the Equation 1:

$\mathrm{HAI}=(1 \mathrm{X} \mathrm{SI})+(10 \mathrm{X}$ SII $)+(100 \mathrm{X}$ SIII $)$

where I, II and III correspond to the number of alteration stages 1,2 and 3 and $\mathrm{S}$ represents the sum of alternations in a given stage.

HAI values of 0 to 10 indicate normal organ functioning; values from 11 to 20 indicate slight alterations in the organ; from 21 to 50 indicate moderate alterations in the organ; values between 50 and 100 indicate severe lesions and values above 100 indicate irreparable lesions in the organ (Poleksic and Mitrovic-Tutundzic, 1994). Based on tissue Repair Capacity, the lesions were classified in three progressive stages: I - tissue reconstruction is possible (structure and function); II - more severe alterations (effects on tissue functions); III - tissue restoration no longer possible. Some cases were selected and photographed with the use of a photomicroscope.

The non-parametric Mann-Whitney test for independent samples with $\mathrm{p}<0.005$ was utilized to compare intensity means of alterations in the two species. The differences between sampling sites were tested using non-parametric ANOVA. The results obtained for each station were compared by Tukey's test. The degree of significance was 95\%. Statistical analysis were carried out using the Past version 1.11. software

\section{Results}

37 individuals of Poecilia vivipara were used, 15 of which were collected in the village of Itapé, 11 at Fazenda Santa Amélia and 11 at Point of Pitú. As these individuals 
Table 1. Classification of the severity of histopathological changes observed in the liver of Poecilia vivipara. Modified from Poleksic and Mitrovic-Tutundzic (1994).

\begin{tabular}{cl}
\hline Stages & \multicolumn{1}{c}{ Alterations } \\
\hline I & Melano macrophage Center \\
& Vacuolated cytoplasm \\
& Irregular form of the hepatocytes \\
& Eosinophil granules in the cytoplasm \\
& Nuclear hipertrophy \\
& Celular hipertrophy \\
& Irregular nuclei \\
& Lateral position of the nucleus \\
& Leukocyte infiltration \\
II $\quad$ Degeneration of the cytoplasm & Degeneration of the nucleus \\
& Pyknotic nuclei \\
& Vacuolated Nuclei \\
III $\quad$ Rectilineation of vessels and parenchyma \\
& Focal necrosis \\
& Tumor
\end{tabular}

were mostly in the juvenile stage whose standard length ranged from 13.06 to $42.54 \mathrm{~mm}$, the total weight ranged from 0.02 to $2.48 \mathrm{~g}$ and liver weight from 0.0010 to $0.0590 \mathrm{~g}$, the at analysis showed that the standard length of individuals were more juveniles in points Vila de Itapé and Fazenda Santa Amélia the average size was of 24 and 24,7 were more juveniles and the average size was of 24 and $24.7 \mathrm{~mm}$ respectively, those of section 4 with a mean of $44.56 \mathrm{~mm}$ would be in the adult phase.

The liver structure in P. vivipara was similar to that of other teleosts. Most of the cells in the hepatic parenchyma presented a polygonal form, rounded nuclei and granular cytoplasm. These cells were distributed irregularly between the sinusoidal vessels, canaliculi and larger vessels, as well as around the bile duct. In some individuals, the fibroblasts were also observed between the hepatocytes. In the hepatic parenchyma, it was possible to observe exocrine pancreas, usually close to blood vessels and ducts. The exocrine pancreas was made of polygonal cells with a prominent central nucleus and with the presence of secretion granules in some of the cytoplasm. These cells presented basophily when stained with hematoxylin (Figure 2a).

Tissue analysis demonstrated that the individuals sampled in points Vila de Itapé, Fazenda Santa Amélia e Ponto do Pitu presented slight alterations (1), such as vacuolation of cellular cytoplasm and irregular formation of hepatocytes. Some cells presented irregularly shaped nuclei. Infiltration by leucocytes (lymphocytes, eosinofils, neutrofils and macrophages) was also observed in some liver areas (Figure 3a). Among the moderate alterations (2), the occurrence of clusters of cytoplasm degeneration, formation of pyknotic nuclei and rectilineation of blood vessels could be observed, and the hepatocytes were disposed in a cord shape (Figure 2c,d). Among the severe alterations (3), necrosis in hepatocytes and formation of fibromas were observed. Most fibromas developed near blood vessels or from conjunctive tissue cells in the tunica intima. In these fibromas, the conjunctive cells multiply and form a thick and fibrous layer below the endothelial cells, where it was also possible to identify infiltration by many leucocytes and macrophages (Figure 3a,b).

At Vila de Itapé, $18.9 \%$ of the individuals had livers with vacuolated hepatocytes with small or large fat vacuoles adding pressure to the nucleus to position itself laterally or irregularly in the cell. Focal and total degeneration points were observed throughout the hepatic parenchyma and in the exocrine pancreas cells. Some lipofucsin granules were also observed in the hepatocytes, as well as rectilineation of vessels and cell cords. In two individuals, fibromas were found at this point that were formed from the tunica adventitia of the bile ducts, and one of the fibromas had expanded throughout almost all of the analyzed area.

The highest frequency of individuals with vacuolated hepatocytes (21.6\%) was found at Fazenda Santa Amélia. Other alterations observed were several points of focal and total degeneration in the hepatic and exocrine pancreas cells, as well as alterations in the pancreatic cells in various regions of the exocrine pancreas and liver. In these individuals, hepatocytes with pyknotic nuclei, invasion of blood cells, rectilineated vessels and cell cords were also observed and in two individuals the occurrence of small fibromas developing next to blood vessels or inside the tunica intima of the vessels was noticed. Besides the fibromas, hypertrophy was also observed in the endothelial cells, and all of them had become quite tumescent.

At Vila de Itapé and Fazenda Santa Amélia of four, $P$. vivipara individuals presented fibromas that were in a more severe state. The fibroma was found inside the tunica intima of the vessel, which was quite thick (Figure 3b). The exocrine pancreas was observed to be in an advanced state of degeneration, which may be related to the advance of cells creating the fibroma. The cellular boundaries of the hepatocits near the neoplasic region were no longer clear and their cytoplasm was full of vacuoles. These alterations led to disarrangement in the hepatic parenchyma and the pancreas, demonstrating that the organ was probably exposed to some stressor agent.

At Ponto do Pitu, $21.6 \%$ of the specimens presented cytoplasm vacuolation. Alterations such as pyknotic nuclei, nuclei in lateral positions and a few clusters of blood cell invasions were also observed, as well as one allergic cluster and one cytoplasmatic degeneration cluster. The exocrine pancreas had a small amount of mucinogen granules, but the format and coloring of the cells were conserved.

The results obtained from analyzing the intensity frequency of alterations in P. vivipara livers demonstrated that the individuals at Fazenda Santa Amélia presented the highest frequency of moderate (2) (40\%) and severe (3) (20\%) alterations, totaling $60 \%$ of the observed changes. At point Vila de Itapé, it was found that most alterations were considered slight (1) (almost 60\%). It was also observed that the percentage of moderate (2) (30\%) and severe (3) $(10 \%)$ alterations was less than what was observed at the 

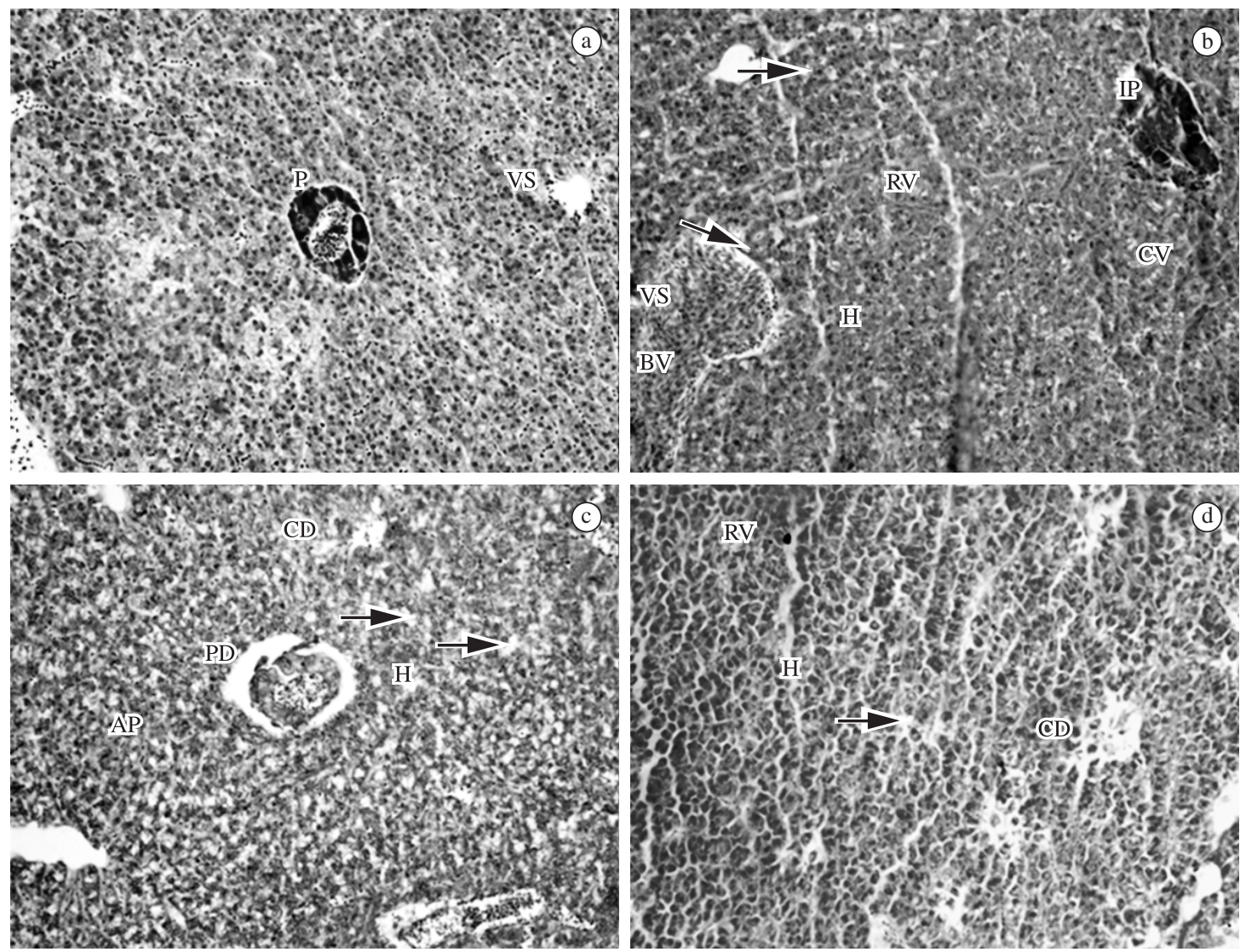

Figure 2. a) Normal Liver of Poecilia vivipara, H \& E (400x); b) Liver with ligth alterations H \& E (400x); c-d) Liver with moderate alterations in the parenchyma and exocrine pancreas, H \& E (400x). AP - Alterations in the liver parenchyma, CD - cellular degeneration, CV - Vessels Congestion, PD - Pancreatic Degeneration; H - Hepatocytes; P - Pancreas; RV Rectiliniear shape of Blood vessels; Arrow - Vacuoles, BV - Blood Vessels and IP - Irregular pancreas.

Fazenda Sta. Amélia point. The sum result of those types of alterations was slightly greater than $40 \%$ (Figure 4). In the point near Ponto do Pitú, the percentage of slight alterations observed $(60 \%)$ was considerably higher than what was found for the other points. Moderate alterations totaled more than $30 \%$ and severe alterations less than 10\% (Figure 4).

Using HAI analysis, it could be observed that the Vila de Itapé and Fazenda Sta. Amélia points presented the highest averages (117.53 and 143.6 respectively). These values demonstrate that individuals at these points present irreparable damage to the organ (Stage III). As for the point near Ponto do Pitú, its average was 87.3, demonstrating that individuals present severe lesions to the organ, so that its recovery is not possible (Transition from stage II to III) (Figure 5).

The results of frequency intensity and HAI analysis indicate that at points Vila de Itapé, Fazenda Santa Amélia e Ponto do Pitu, individuals were subjected to environmental stress factors over a long period of time given that they present high frequency of moderate and severe alterations and high HAI averages. Results from the statistical analysis demonstrated that there was no statistically significant difference between the sampled points, indicating that through histopathological analysis both points present signs of environmental degradation. It was not possible to compare environmental quality for all points defined in the pilot sample given that specimens of Poecilia vivipara were not sampled at the Jardim das Acácias and Caminho das Sesmarias points.

\section{Discussion}

The results of this study demonstrate that the high frequency of histopathological alterations found in the liver of Poecilia vivipara specimens is probably associated to alterations on the aquatic environmental quality, related to some parameters verified by Pinho (2001) such as discharges of domestic and industrial wastes, detergents, pesticides and residues from the Coograp dairy product industry. This author has observed that the phosphorus concentration in the Cachoeira river basin is 25 times greater than what is determined by the CONAMA resolution 357 for class 2 rivers (Brasil, 2005).

Klumpp et al. (2002) found a growing increase in phosphate and nitrogen concentrations along the river 

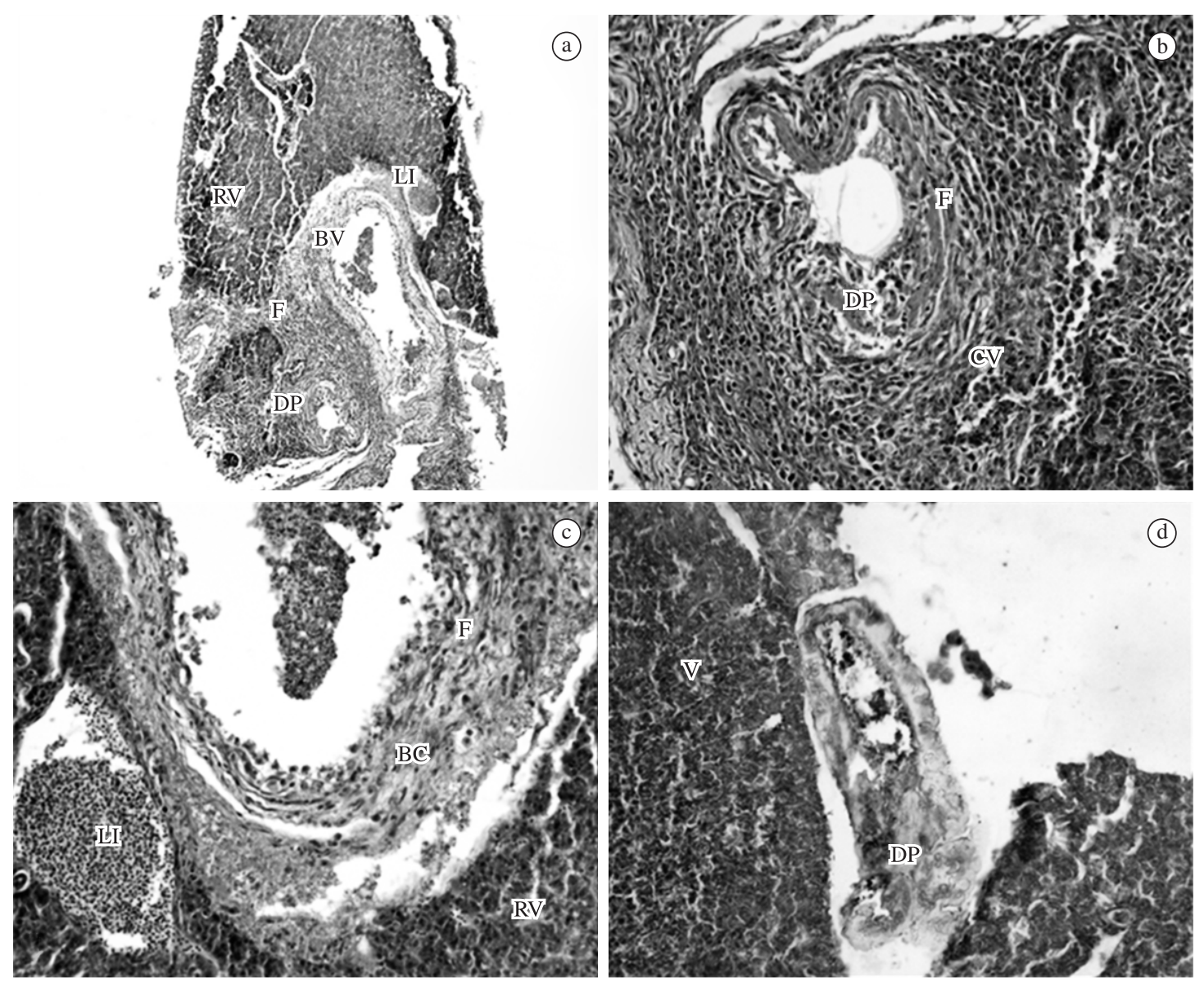

Figure 3. a-c) Fibroid of blood vessels of the liver; d) Liver of Poecilia vivipara with severe alterations; A - H \& E (200×), B to D - H \& E (400×). BC - Blood Cell, BV - Blood Vessels, CV - Vessels Congestion, F - Fibroma; DP - Degeneration of the Exocrine Pancreas, LI - Leukocyte Infiltration, RV - Rectiliniear shape of Blood Vessels; V-vacuole.

with a drastic increase in phosphate concentration and a $100 \%$ increase in nitrogen observed after Itabuna which indicates a strong influence by urban wastes on nutrient concentrations in the water. Besides the high concentrations of phosphate and nitrogen, these authors found that the concentrations of certain metals such as copper, chromium and aluminum along the river have increased. He attributed this high amount of metals and eutrophication of the Cachoeira river agriculture (due to the use of fungicides containing copper in cocoa plantations), mining and urban effluents from the region. Pinho (2001) also observed that Dissolved Oxygen (DO), the biological demand of oxygen (BDO) and coliforms thermotolerant (total and fecal) also presented values above the standards established by the CONAMA resolution, mainly in the lower portions of the basin.

Fidelman (2005) points out that activities such as inappropriate agricultural and ranching, deforestation, urban and industrial activities contribute to environmental quality degradation. Mangabeira et al. (2004) notes that recent studies have demonstrated that waters in the Cachoeira river basin are polluted by various metals and that water and sediment samples may reflect only a momentary situation. These authors have observed high chromium concentrations in the water, sediment and the roots of Eichhornia crassipes. Klumpp et al. (2002) observed chromium along the river with an increase in the concentration of this metal, which was found in the regions closer to Itabuna. This increment possibly attributed to effluent discharges from tanneries in the Itabuna region. The contribution of domestic wastes cannot be excluded. These authors have observed that except for Vila Cachoeira, there was an increase in aluminum concentration moving towards the lower reaches of the river. The water treatment station in Itabuna is probably the main source for aluminum in the Cachoeira river, using aluminum sulfate for coagulation and flocculation of water from the Almada river a few kilometers upstream, so as to improve water turbidity and color.

The results obtained from $P$. vivipara have demonstrated that the high frequency in cytoplasmatic vacuolation is probably associated to the action of chemical substances that are released into the environment and Dyk et al. (2007) noted that inhibition in protein synthesis and accumulation of lipids is associated to the response of hepatocytes to toxic agents. Fanta et al. (2003) points out that the vacuolation process can be considered a normal action by the liver or an 
Frequency of histopathological alteration intensity

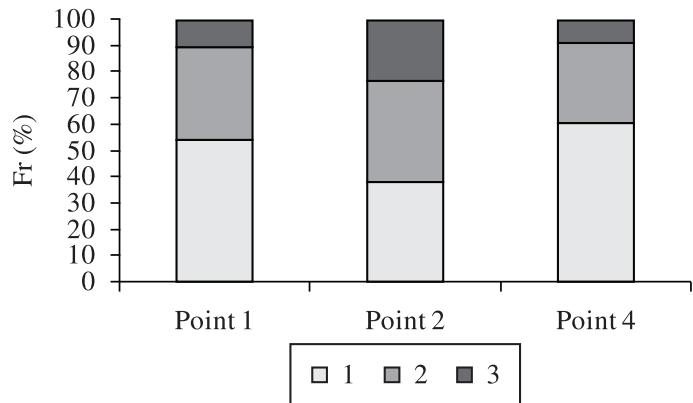

Figure 4. The relative frequency of histopathological alteration intensity observed in the liver of Poecilia vivipara per sample point in the Cachoeira river. $1=$ light alteration, $2=$ moderate and $3=$ severe alteration .

\section{Mean HAI}

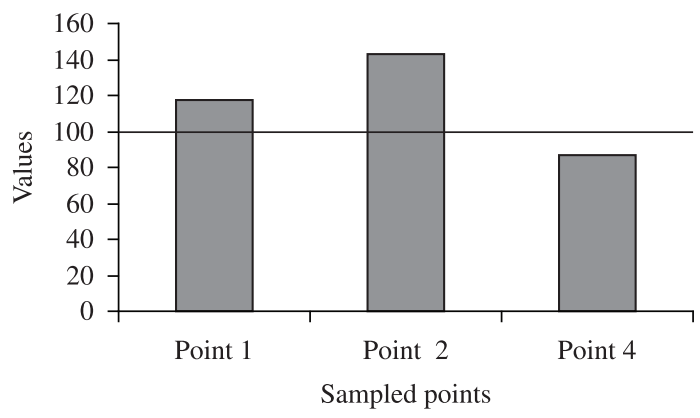

Figure 5. Values of index of Histopathologic alteration (IHA) to the liver of Poecilia vivipara for points sampled in the Cachoeira river.

indication of a state of stress, due to the high energy demand. For authors such as Thomas (1990), Köhler et al. (1992), Teh et al. (1997), changes such as hepatocyte vacuolation, glycogen depletion, inflammation, alteration in the shape of sinusoidal vessels and neoplasmas can be interpreted as responses to environmental stress and are thus considered to be histopathological indicators of environmental quality. Olurin et al. (2006), studying the histopathological response of a liver to glyphosate, also observed that this type of degeneration in Clarias gariepinus Burchell (1822) was associated with intoxication by pollutants and Takashima and Hibyia (1995 apud Meletti et al., 2003) warn that cellular degeneration through fat refers to a pathological condition in which there are numerous cells with high fat content.

Walters and Plumb (1980) pointed out that toxic substances may modify the chemical composition of water, which may be lethal to fish or may stress them enough to predispose them to disease. These authors further noted that congestion in blood vessels and an increase in cell volume are responses by hepatocytes to the presence of toxic substances, including metals such as cadmium and zinc. Martinez et al. (2004) reported that fish contamination from lead may trigger a wide range of metabolic factors and physiological alterations seen as secondary responses to stress.

The high frequency of pathological alterations observed in moderate and severe degrees at points Vila de Itapé and Fazenda Sta. Amélia have influenced the high HAI value for these points, indicating that even if there had been improvements to the environmental conditions, the liver had been so highly affected that its recuperation would no longer be possible. The degree of these alterations is probably related to prolonged exposure to action by contaminants. Flores-Lopes et al. (2007) have pointed out that these alterations may be associated to the response to some stressor agent present in the aquatic environment that is not detected in traditional physical-chemical analyses. At these points, four specimens of $P$. vivipara with fibromas were observed, one in a more severe state, presenting a quite thick tunica intima in the vessel and the exocrine pancreas at an advanced stage of degeneration. These alterations demonstrated that the organ had probably been exposed to prolonged action by some stressor agent. From the average standard length of specimens examined in this study, we that the higher frequency of alterations was observed mostly in young individuals other than adults, making the first ones more susceptible to stressors.

The results of histopathological analysis corroborate the results obtained using HAI, which demonstrated greater severity in histopathological alterations at points Vila de Itapé and Fazenda Sta. Amélia, which is probably an indication of greater environmental degradation. Similar results were observed by Fanta et al. (2003), who observed that the liver is an organ that suffers serious morphological alterations in fish exposed to pesticides, such as nuclear alterations, pyknotic nuclei and lateral position, as well as intense vacuolation. Authors such as Sakr and Jamal Al Lial (2005), Peebua et al. (2006) and Scaff and Scussel (2008) have also observed that histopathological alterations such as hepatocyte vacuolation, focal and total necrosis, infiltration by leucocytes, pyknotic nuclei and necrosis due to hepatocyte apoptosis are associated to individuals being exposed to environments contaminated from toxic substances.

The results obtained in this study differ from those verified by Pinho (2001), for whom Vila de Itapé and Fazenda Santa Amélia were considered as having good environmental quality, since at those points low concentrations of fecal and total coliforms thermototolerant, a high concentration of dissolved oxygem concentration and low biological demand of oxygen (BDO) were observed. Although these environments may present coliform and total coliform, $\mathrm{BDO}$ and $\mathrm{DO}$ values that are within the standard established by CONAMA resolution 357 from 2005 , these parameters are probably not responsible for the histopathological alterations. These data make it clear that other contaminants such as detergents, heavy metals and others must be acting on the environment, leading to the development of pathologies observed in specimens. Frieberg et al. (1971) apud (Olojo, 2005) analyzing the 
bioaccumulation of lead in the liver observed that this metal promotes degeneration of the hepatic cells.

The water quality study for the Cachoeira river carried out by Pinho (2001), at points close to those sampled in this study, revealed that raw impact from the city of Itapé did not impact that stretch. However, this same author characterized the area corresponding to the Fazenda Sta. Amélia point as being in a process of degradation of water quality, due to receiving waste discharges from various food factories and the local slaughterhouse.

An elevated frequency of slight alterations was observed for the point near Ponto do Pitú, reflected in the HAI result for this point, which presented a lower average (87.2) compared to that for point Vila de Itapé and Fazenda Sta. Amélia (117.5 and 143.6 respectively). Although the average for this point was lower than for the others, it also demonstrated that there are indications of environmental degradation. This area was also characterized as having had an impact by Pinho (2001) as the results obtained for phosphorus presented a high concentration in the basin. The author also observed that dissolved oxygen (DO), biological demand of oxygen (BDO) and coliforms (total and fecal) presented values outside the standards established by the aforementioned CONAMA resolution, mainly in the lower portion of the basin (regions between Itabuna and Ilhéus).

This point is characterized by being near a rural area and near the city of Itabuna, where human influence may be encountered, with the discharge of domestic and industrial waste coming from the urban perimeter. Lúcio (2010) showed in studies on the Cachoeira river that in the sampling area close to this point besides the contribution that showed the sewer upstream, the entry of tributaries that are likely to pour into the river are more refractory organic matter with the primary source pastoral activities.

The results obtained using statistical tests and HAI demonstrate that the Vila de Itapé, Fazenda Sta. Amélia and near Ponto do Pitú points presented indications of degradation of the environmental quality, with no statistically significant difference found among them, indicating that they are ecologically threatened. Due to the fact that Fazenda Santa Amélia presents a higher frequency of severe and average alterations and higher HAI average, it may be considered as having the worst environmental quality compared to the others, as it fits into the category having the most irreparable liver damages. In other words, even if environmental conditions are reestablished, the organ will not recover.

The present data clearly shows the need for more studies within the Cachoeira River Basin. It is considered important to conduct more detailed studies on the chemical substances present in the river's water, which may lead to a better accuracy for the occurrence of histopathological responses in the liver of fish species. Thus, the results obtained in $P$. vivipara are important, given that the Cachoeira river is undergoing an anthropogenic action along the river and at certain points the environment is now eutrophized.

\section{Conclusion}

The results of this study may imply that the Cachoeira river is undergoing a process of environmental degradation due to the high presence of severe pathological alterations in the liver of Poecilia vivipara. Furthermore, these results associated with data supplied by other studies indicate that environmental agents probably pesticides, heavy metals, sewage and others should be acting on these populations. Thus, it is imperative that mitigation measures such as reducing the release of waste into the river, deforestation and pesticide use are taken to ensure that no damage will occur in the populations of these species.

Acknowledgements - We would like to thank Augusta Miranda, Andressa Teodósio and Carolyne Santana for collaborating in collecting and screening fish for analysis. Likewise, we wish to thank the thesis committee members Dr. Guisla Boehs and Dr. Aparecida do Carmo Zerbo Tremacoldi for their willingness to collaborate and share their knowledge in order to improve this investigation.

\section{References}

ADAMS, SM., SHUGART,IR., SOUTHWORTH,GR. and HINTON, DE., 1990. Application of biomarcators in assessing the health of fish populations expereriencing contaminat stress. In MCCARTHY, JF. And SHUGART, LR., (eds.). Biomarkers of Environmental Contamination. Lewis Publishers, Boca Raton. cap.19, p. 333-353.

BERNET, D., SCHMIDT, H. and MEIER, W., 1999. Histopathology in fish: proposal for a protocol to assess aquatic pollution. Journal Fish Disease, vol. 22, p. 25-34. http://dx.doi.org/10.1046/j.13652761.1999.00134.x

BRESEGHELO, L., CARDOSO, MP., BORGES-DEOLIVEIRA, R., COSTA, MF., BARRETO JCB., SABÓIA-MORAIS, SMT. and YAMADA, AT., 2004. Effects of sodium fluoride in gill epithelium of Guppy fish (Poecilia vivipara). Brazilian Journal of Veterinary Research and Animal Science, vol. 41, p. 274-280.

BRUSCHI JUNIOR, W., MALABARBA, LR. and SILVA, JFP. 2000. Avaliação da Qualidade Ambiental dos riachos através das Taxocenoses de peixes. In Universidade Federal do Rio Grande do Sul. Centro de Ecologia. Carvão e Meio Ambiente. Porto Alegre: Ed. UFRGS. p. 803-809.

Brasil. Conselho Nacional do Meio Ambiente. Resolução n 357, de 17 de março de 2005. Dispõe sobre a qualidade dos corpos de água e diretrizes ambientais para o seu enquadramento, bem como estabelece as condições e padrões de lançamento de efluentes e da outras providências. Diário Oficial da República Federativa do Brasil, Brasília, DF, 18 mar. 2005. Available from: <http:// www.mma.gov.br/port/conama/res/res05/res35705.pdf>.

DYK, JC., PIETERSE, GM. and van VUREN, JHJ., 2007. Histological changes in the liver of Oreochromis mossambicus (Cichlidae) after exposure to cadmium and zinc. Ecotoxicology and Environmental Safety, vol. 66, p. 432-440. PMid:16364439. http://dx.doi.org/10.1016/j.ecoenv.2005.10.012

FANTA, E., RIOS, FS., ROMÃO, S., VIANA, ACC. and FREIBER, S., 2003. Histopatology of the fish Corydoras paleatus contaminated with sublethal levels of organophosphorus in water and food. Ecotoxicology and Environmental Safety, vol. 54, p. 119-130. http://dx.doi.org/10.1016/S0147-6513(02)00044-1 
FIDELMAN, P. I. J. 2005. Contribuição para Mitigação dos Impactos da Macrófita Aquática Eichhornia Crassipes sobre a Zona Costeira da Região Sul da Bahia. Gestão Costeira Integrada. Revista de Gestão Costeira Integrada para Países de Língua Portuguesa. Itajaí, v. 4, p. 1-5

FLORES-LOPES, F. and MALABARBA, LR., 2007. Alterações histopatológicas observadas no fígado de Lambarí Astyanax jacuhiensis (Cope, 1894) (Teleostei, Characideae) sob influência de efluentes petroquímicos. Biociência, vol. 15, p. 166-172.

GONZALEZ, G., CRESPO, S. and BRUSKE, J., 1993. Histocytological study of the liver of the cabrilla sea bass, Serranus cabrilla (Teleostei, Serranidae), an available model for marine fish experimental studies. Journal of Fish Biology, p. 363-373. http://dx.doi.org/10.1111/j.1095-8649.1993.tb00571.x

HOSE, JE., MCGURK, MD., MARTY, GD., HINTON, DE., BROWN, ED. and BAKER, TT., 1996. Sublethal effects of the Exxon Valdez oil spill on herring embryos and larvae: morphological, cytogenetic, and histopathological assessments 1989-1991. Canadian Journal Fish Aquatic Sciense, vol. 53, p. 2355-2365.

KLUMPP, A., BAUER, K., FRANZ-GERSTEIN, C. and MENEZES, M., 2002. Variation of nutrient and metal concentrations in aquatic macrophytes along the Rio Cachoeira in Bahia (Brazil). Environment International, vol. 28, p. 165-171. http://dx.doi. org/10.1016/S0160-4120(02)00026-0

LOBO, EA., CALLEGARO, VLM. and BENDER, EP., 2002. Utilização de algas diatomáceas epilíticas como indicadores da qualidade da água em rios e arroios da região hidrográfica do Guaíba, RS, Brasil. Santa Cruz do Sul: EDUNISC. 127 p.

KÖHLER, A., DEISEMANN, H. and LAURITZEN, B., 1992. Histological and cytochemical indices of toxic injury in the liver of dab Limanda limanda. Marine Ecology Progress Series, vol. 91, p. 141-153.

LUCINDA, PHF. and COSTA, WJEM ., 2007. Família Poeciliidae. In BUCKUP, PA., MENEZES, NA. and GHAZZI, MS., (Eds.). Catálogo das espécies de peixes de água doce do Brasil. Rio de Janeiro: Museu Nacional. p. 134-137. Série livros, no. 23.

LÚCIO, MZTPQL., 2010. Biogeoquímica do rio Cachoeira (Bahia, Brasil). Ilhéus: Universidade Estadual de Santa Cruz. Tese de Mestrado em Sistemas Aquáticos Tropicais.

MALABARBA, LR. and REIS, RE., 1987. Manual de Técnicas para a preparação de Coleções Zoológicas. Campinas: Sociedade Brasileira de Zoologia. 14 p. no. 36: Peixes.

MANGABEIRA, PAO., LABEJOF, L., LAMPERTI, A., DE ALMEIDA, A-AF., OLIVEIRA, AH., ESCAIG, F., SEVERO, MIG., SILVA, DC., SALOES, M., MIELKE, MS., LUCENA, ER., MARTINS, MC., SANTANA, KB., GAVRILOV, KL., GALLE, P. and LEVI-SETTI, R., 2004. Accumulation of chromium in root tissues of Eichhornia crassipes (Mart.) Solms. in Cachoeira river-Brazil. Applied Surface Science, p. 231-232.

MARTINEZ, CBR., NAGAE, MY., ZAIA, CTBV. and ZAIA, DAM., 2004. Acute morphological and physiological effects of lead in the neotropical fish Prochilodus lineatus. Brazilian Journal of Biology, vol. 64, p. 797-807.

MAZON, AF., CERQUEIRA, CCC., MONTEIRO, EAS. and FERNANDES, MN. 1999. Acute copper exposure in freshwater fish: Morphological and physiological effect. In VAL, AL. and ALMEIDA-VAL, VMF. Biology of Tropical Fishes. Manaus: INPA. p. 263-275.
MELETTI, PC., ROCHA, O. and MARTINEZ, CBR., 2003. Avaliação de Degradação Ambiental na Bacia do rio Mogi-Guaçu por meio de testes de toxicidade com sedimento e de análise histopatológicas em peixes. In BRIGANTE, J. and ESPINDOLA, ELG., (Eds). Limnologia Fluvial: Um Estudo o rio Mogi-Guaçu. São Carlos. p. 149-180.

NACIF, PGS., 2000. Ambientes naturais da bacia hidrográfica do rio Cachoeira, com ênfase nos domínios pedagógicos. Viçosa: Universidade Federal de Viçosa. Tese de Doutorado em Solos.

OLIVEIRA-RIBEIRO, CA., VOLLAIRE, Y., SANCHEZCHARDI, A. and ROCHE. H., 2005. Bioaccumulation and the effects of organochlorine pesticides, $\mathrm{PAH}$ and heavy metals in the Eel (Anguilla anguilla) at the Camargue Nature Reserve, France. Aquatic Toxicology, vol. 74, p. 53-69. PMid:15967515. http://dx.doi.org/10.1016/j.aquatox.2005.04.008

OLOJO, EAA., OLURIN, KB., MBAKA, G. and OLUWEMIMO, AD., 2005. Histopathology of the gill and liver tissues of the African catfish Clarias gariepinus exposed to lead. African Journal of Biotechnology, vol. 4, p. 117- 122.

OLURIN, KB., OLOJO, EAA., MBAKA, GO. and AKINDELE, AT., 2006. Histopathological responses of the gill and liver tissues of Clarias gariepinus fingerlings to the herbicide,glyphosate. African Journal of Biotechnology, v. 24, p. 2480-2487.

PEEBUA, P., KRUATRACHUE, M., POKETHITYOOK, P. and KOSIYACHINDA, P., 2006. Histological effects of contaminated dediments in Mae Klong river tributaries, Tailand, on Nile tilapia, Oreochromis niloticus. Science Asia, v. 32, p. 143-150. http:// dx.doi.org/10.2306/scienceasia1513-1874.2006.32.143

PINHO, AG., 2001. Estudo da qualidade das águas do Rio Cachoeira-Região Sul da Bahia. Ilhéus: Universidade Estadual de Santa Cruz. 133 p. Tese de Mestrado em Desenvolvimento Regional e Meio Ambiente.

POLEKSIC, V. and MITROVIC-TUTUNDZIC, V., 1994. Fish gills as a monitor of sublethal and chronic effects of pollution. In MÜLLER, R. and LLOYD, R., (Eds.). Sublethal and Chronic effects of Pollutants on Freshwater Fish. Cambridge: Cambridge Univ. Press. p. 339-352.

SAKR, SA. and JAMAL AL LIAL, SM., 2005. Fenvalerate induced histopathological and histochemical and histochemical changes in the Catfish Clarias gariepinus. Journal of Applied Sciences Reseach, v. 3, p. 263-267.

SCAFF, RMC. and SCUSSEL, VM., 2008. Ultra-structural and histochemical analysis of channel Catfish (Ictalurus puncatus) liver treated with fumosin B1. Brazilian Archives of Biology and Technology, vol. 2, p. 333-344.

SCHIAVETTI, A., SCHILLING, AC. and OLIVEIRA, HT. 2002. Caracterização sócio-ambiental da bacia Hidrográfica do rio Cachoeira, Sul da Bahia, Brasil. In SCHIAVETTI, A. and CAMARGO, AFM. Conceitos de Bacias Hidrográficas. Ilhéus: EDITUS. 289 p. Teorias e Aplicações.

SCHMALZ, WF., HERNANDEZ, AD. and WEIS, P., 2002. Hepatic histopathology in two populations of the mummichog, Fundulus heteroclitus. Marine Environmental Research, vol. 54, p. 539-542. http://dx.doi.org/10.1016/S0141-1136(02)00132-0

SOUZA, VL., SILVA, DC., SANTANA, KB., MIELKE, MS., ALMEIDA, AAF., MANGABEIRA, PAO. and ROCHA, EA., 2009. Efeitos do cádmio na anatomia e na fotossíntese de duas macrófitas aquáticas. Acta Botanica Brasilica, p. 343 -354. 
STEBBING, ARD., 1985. A possible synthesis. In BAYNE, bl., (Eds.). The effects of stress and pollution on marine animals. New York: Praeger.

TEH, SJ., ADAMS, SM. and HINTON, DE. 1997. Histopathologic biomarkers in feral freshwater fish populations exposed to different types of contaminant stress. Aquatic Toxicology, vol. 37, p. 51-70. http://dx.doi.org/10.1016/S0166-445X(96)00808-9

THOMAS, P., 1990. Molecular and Biochemical Responses of Fish to Stressors and Their Potential Use in Environmental Monitoring. American Fisheries Society Symposium, vol. 8, p. 9-28.
WALTERS, GR. and PLUMB, JA., 1980. Environmental stress and bacterial infection in channel catfish, Ictalurus punctatus Rafinesque. Journal of Fish Biology, vol. 17, p.177-185. http:// dx.doi.org/10.1111/j.1095-8649.1980.tb02751.x

WINKALER, EU., SILVA, AG., GALINDO, HC. and MARTINEZ, CBR., 2001. Biomarcadores histológicos e fisiológicos para o monitoramento da saúde de peixes de ribeirões de Londrina, Estado do Paraná. Acta Scientiarum, vol. 23, p. 507-514.

ZAGATTO, PA., 2006. Ecotoxicologia. In ZAGATTO, PA. and BERTOLETTI, E., (Eds.). Ecotoxicologia Aquática-Princípios e Aplicações. São Paulo: Editora Rima. p. 413-427. 